\title{
Organic carbon flux and particulate organic matter composition in Arctic valley glaciers: examples from the Bayelva River and adjacent Kongsfjorden
}

\author{
Zhuo-Yi Zhu ${ }^{1}$, Ying Wu ${ }^{1}$, Su-Mei Liu ${ }^{2}$, Fred Wenger ${ }^{3}$, Jun Hu ${ }^{1}$, Jing Zhang ${ }^{1}$, and Rui-Feng Zhang ${ }^{1}$ \\ ${ }^{1}$ State Key Laboratory of Estuarine and Coastal Research, East China Normal University, Shanghai, China \\ ${ }^{2}$ Key Laboratory of Marine Chemistry Theory and Technology Ministry of Education, Ocean University of China, Qingdao, \\ Shandong, China \\ ${ }^{3}$ Norwegian Water resources and Energy Directorate, Oslo, Norway
}

Correspondence to: Zhuo-Yi Zhu (zyzhu@sklec.ecnu.edu.cn)

Received: 9 August 2015 - Published in Biogeosciences Discuss.: 22 September 2015

Revised: 2 January 2016 - Accepted: 6 February 2016 - Published: 22 February 2016

\begin{abstract}
In the face of ongoing global warming and glacier retreat, the composition and flux of organic matter in glacierfjord systems are key variables for updating the carbon cycle and budget, whereas the role of Arctic valley glaciers seems unimportant when compared with the huge Greenland Ice Sheet. Our field observations of the glacier-fed Bayelva River, Svalbard, and the adjacent Kongsfjorden allowed us to determine the compositions of particulate organic matter from glacier to fjord and also to estimate the flux of organic carbon, both for the river and for Svalbard in general.

Particulate organic carbon (POC) and dissolved organic carbon (DOC) in the Bayelva River averaged 56 and $73 \mu \mathrm{M}$, respectively, in August, 2012. Amino acids (AAs) and phytoplankton carbon accounted for $\sim 10 \%$ of the bulk POC in the Bayelva River, while AAs represented $>90 \%$ of particulate nitrogen (PN) in fjord surface water, suggesting the strong in situ assimilation of organic matter. Bacteria accounted for 13 and $19 \%$ of the POC in the Bayelva River and the Kongsfjorden, respectively, while values for PN were much higher (i.e., $36 \%$ in Kongsfjorden).

The total discharge from the Bayelva River in 2012 was $29 \times 10^{6} \mathrm{~m}^{3}$. Furthermore, we calculated the annual POC, DOC, and PN fluxes for the river as $20 \pm 1.6$ tons, $25 \pm 5.6$ tons, and $4.7 \pm 0.75$ tons, respectively. Using the POC content and DOC concentration data, we then estimated the annual POC and DOC fluxes for Svalbard glaciers. Although the estimated POC $\left(0.056 \pm 0.02 \times 10^{6}\right.$ tons year $\left.^{-1}\right)$ and DOC $\left(0.02 \pm 0.01 \times 10^{6}\right.$ tons year $\left.^{-1}\right)$ fluxes of Svalbard
\end{abstract}

glaciers are small in amount, its discharge-weighted flux of DOC was over twice higher than other pan-Arctic glacier systems, suggesting its important role as a terrestrial DOC source.

\section{Introduction}

The composition and flux of organic carbon are two key factors in the study of global climate change and material cycling. Current retreat of Arctic glaciers, as a consequence of global warming, not only contributes to sea-level rise but also serves to increase the input of terrigenous material to the ocean. This in turn impacts the composition of oceanic organic carbon and modifies the carbon flux, with potential ramifications for global climate variability and material cycles.

Terrigenous dissolved organic matter (DOM) in the Arctic Ocean exhibits a considerably shorter lifespan than that in the Pacific and Atlantic oceans (Opsahl et al., 1999). Furthermore, despite the depleted nature of ${ }^{14} \mathrm{C}$ values of glacial DOM, which results in old apparent ${ }^{14} \mathrm{C}$ ages, significant proteinaceous signals (Dubnick et al., 2010) and a high labile proportion (23-66\%; Hood et al., 2009) were identified in the glacier meltwater DOM. This decoupling of age and stability in glacial DOM is probably due to the contribution of subglacial microbial communities (Sharp et al., 1999). The main sources of organic carbon in glacial meltwa- 
ter include bed rock and paleosoil at the bottom of glaciers and subglacial microbial activity (Sharp et al., 1999), the proglacial/ice margin (e.g., soils) (Hodson et al., 1998), and the cryoconite and supraglacial microbial contribution (Anesio et al., 2010; Irvine-Fynn et al., 2012). Unlike temperate glaciers (e.g., alpine glaciers), suspended sediment in high Arctic glaciers becomes increasingly available to the fluvial system through the melt season (Hodson et al., 1998) and hence the particulate organic carbon (POC) output may remain at an elevated level throughout the melt season. Indeed, the flux of POC in high Arctic glacial meltwater is typically higher than that of DOC (e.g., Bhatia et al., 2013), while the labile proportion is relatively low (9\%) (Lawson et al., 2014). As terrestrial DOC travels much farther away than POC does (Dittmar and Kattner, 2003), the DOC and POC impact of glacier meltwater to the ocean is different. By means of DOC, though both the total flux amount and refractory proportion are lower, glacier meltwater can exert great impact to the entire Arctic Ocean, whereas by means of POC, the glacier meltwater enhances the role of adjacent regional fjords and makes the fjords more important in the carbon cycle and budget (Smith et al., 2015).

To date, most studies of organic matter in Arctic glacial meltwater have focused on the Greenland Ice Sheet (e.g., Bhatia et al., 2013; Lawson et al., 2014), with little attention paid to smaller valley glaciers, such as those on Svalbard (Irvine-Fynn et al., 2012; Kuliñski et al., 2014; Tye and Heaton, 2007). However, a comparison of Alaskan glaciers (Hood et al., 2009) and the Greenland Ice Sheet (Bhatia et al., 2013) reveals that valley glaciers exhibit higher area-weighted fluxes of organic carbon. Although regional fluxes of POC have been estimated for glaciers on Svalbard (Kuliñski et al., 2014), the area-weighted and dischargeweighted fluxes of organic carbon for the entire archipelago has yet to be determined. Furthermore, to our knowledge, little or no information exists on potential labile proportions in Svalbard glacial meltwater particulate organic matter (POM), or on the POM composition of glacier meltwater that enters adjacent fjords.

We carried out field observations of the Bayelva River and Kongsfjorden in summer of 2012. Using amino acid (AA) enantiomers and phytoplankton pigments as biomarkers, we first focused on variations in POM composition between glacial meltwater and the fjord. Subsequently, we employed 2012 discharge data for the Bayelva River to estimate the riverine flux of organic matter, and up-scaled this flux to cover the whole of Svalbard with representativeness discussion. Finally, we compared the organic carbon flux in Svalbard with that of other Arctic glaciers, including the Greenland Ice Sheet.

\section{Materials and methods}

The Bayelva River in Ny-Ålesund, Svalbard, is the principal meltwater channel draining the Austre Brøggerbreen Valley glacier into Kongsfjorden (also known as Kings Bay). Downstream of the glacier terminus, a hydrologic station collects river discharge data during the freshet. The physical and biological characteristics of Kongsfjorden have been summarized by Hop et al. (2006). Nitrogen limitation of primary production occurs during summer months (Rokkan Iversen and Seuthe, 2011), when stratification of the water column and input of nutrient-depleted glacial meltwater results in oligotrophic surface water in the inner fjord (e.g., increase proportion of cyanobacteria and cryptophytes in surface phytoplankton communities; Hop et al., 2002). Moreover, where turbid meltwater has yet to mix with clear sea water, phytoplankton growth is limited by reduced illumination (Svendsen et al., 2002). In the outer fjord, the high abundance of zooplankton exerts considerable grazing pressure on algae, resulting in a relatively low standing stock in surface water (Hop et al., 2002).

The study area is shown in Fig. 1a. The Bayelva River is $\sim 4 \mathrm{~km}$ long and occupies a basin underlain by Permian and Carboniferous lithologies (Hjelle, 1993). In normal years, river flow begins in early-mid June, while the riverbed and banks are still frozen, and for approximately 10 days the water flows clear. Subsequently, the river flow becomes turbid and remains so until the river refreezes in autumn (usually in September/October). In Kongsfjorden, which lacks a sill at its mouth, the exchange of intermediate and deep fjord water with Arctic Water and Atlantic Water is facilitated by a prominent trench that decreases in depth towards the shallow continental shelf (Svendsen et al., 2002).

\subsection{Monitoring discharge of the Bayelva River}

Approximately $700 \mathrm{~m}$ upstream from where the river enters the fjord, a monitoring station (NVE; Fig. 1b) is operated by the Norwegian Water Resources and Energy Directorate, and includes an artificial concrete flume with a so-called crump weir. Water level is measured using a system comprising a float, counterweight, and encoder, and the data are stored in a logger. Ultimately, water discharge is determined using a rating curve. In 2012, discharge data were collected between 15 June and 1 October. For the remainder of the year, data collection was not possible due to freezing.

\subsection{Field observations and biogeochemical sampling}

We conducted our field investigation between 6 and $19 \mathrm{Au}-$ gust 2012. The area sampled covers both the Bayelva River basin and Kongsfjorden (Fig. 1b). For the terrestrial stations, we carried out our investigation on foot, collecting samples with a pre-cleaned bucket. Using a portable water quality meter (WTW ${ }^{\circledR}$, multi 350i, Germany), which was 

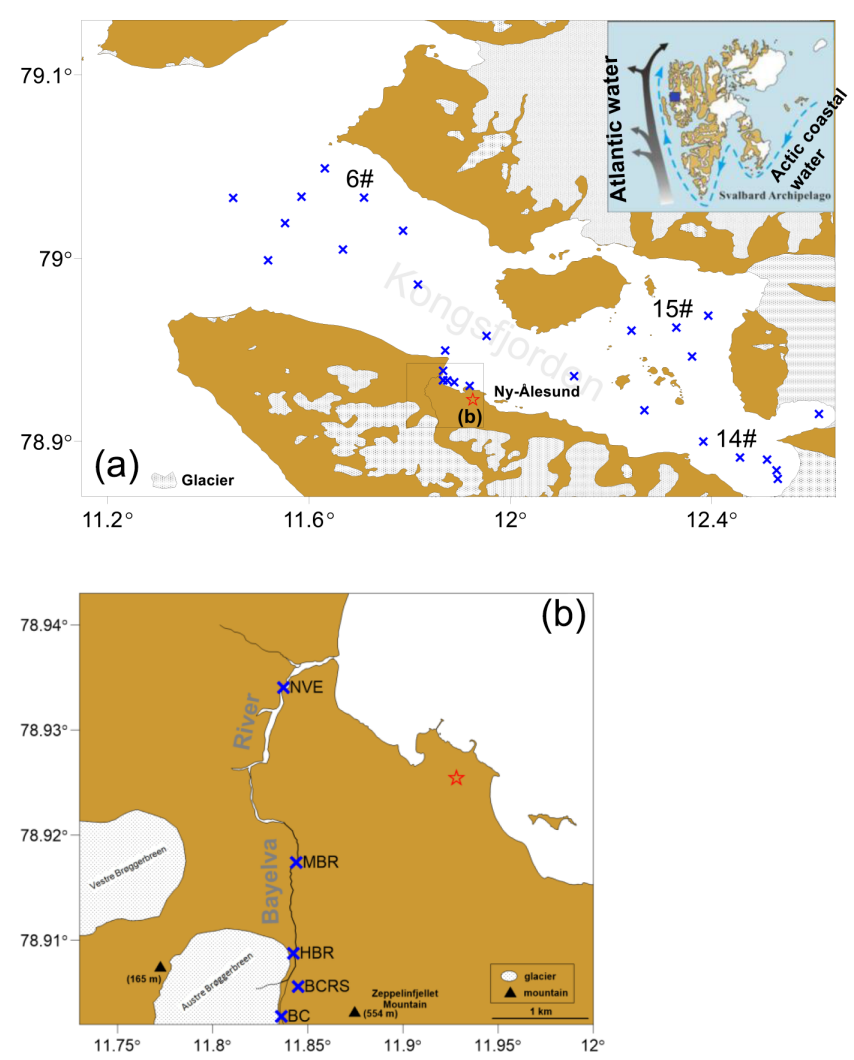

Figure 1. Study area and sampling stations in (a) the Kongsfjorden and (b) the Bayelva River in August 2012 (red star indicates the location of Ny-Ålesund; a schematic of the glaciers is shown as inset in panel a).

calibrated daily, we measured salinity/conductivity, temperature, $\mathrm{pH}$, and dissolved oxygen. For the marine/estuarine stations, sampling was carried out from the R/V Tiesten or a rubber boat. When on the R/V Tiesten, we obtained salinity, temperature, fluorescence, and turbidity profiles using a CTD (SD204, SAIV A/S, Norway) and discrete water samples were usually collected at two layers (i.e., surface and near-bottom layer $15-20 \mathrm{~m}$ above seabed) via Niskin samplers. For comparison, discrete water samples were also measured with the portable water quality meter. When on rubber boat, only surface waters were collected/measured. Both terrestrial and marine samples were returned immediately to the marine laboratory for processing. Additionally, clean floating ice, without visible soil or sediment, was collected from the fjord for analysis of dissolved nutrients.

In the laboratory, suspended particles were concentrated onto pre-combusted glass fiber membranes (Whatman ${ }^{\circledR}$, $\mathrm{GF} / \mathrm{F}$, pore size $0.7 \mu \mathrm{M}$ ) under a mild vacuum, before being analyzed for total hydrolyzable particulate amino acids (THPAA), particulate nitrogen (PN), phytoplankton pigments, and particulate organic carbon and its stable isotopes (POC and $\delta^{13} \mathrm{C}$ ). Filtration volume ranged from 0.09 to $5.4 \mathrm{~L}$, depending on the concentration of suspended particles. Dur- ing filtration, visible swimmers (Calanoida and other zooplankton) were observed in fjord samples, especially those from open western areas. Whenever possible, all swimmers were removed from the membrane prior to storage, using clean tweezers. Water samples for dissolved nutrients were filtered through acid-cleaned acetate cellulose filters (pore size $0.45 \mu \mathrm{m}$ ), whereas samples for DOC were filtered using nylon filters (pore size $0.45 \mu \mathrm{m}$ ) and a syringe. Nutrient samples were poisoned with $\mathrm{HgCl}_{2}$ and stored at $4{ }^{\circ} \mathrm{C}$ in the dark. All other samples were kept frozen $\left(-20^{\circ} \mathrm{C}\right)$ until laboratory analysis.

\subsection{Instrumental measurements}

Our measurement of AA enantiomers followed the protocol of Fitznar et al. (1999), a detailed description of which is provided by Zhu et al. (2014). Briefly, GF/F filters were first freeze-dried and then hydrolyzed with $\mathrm{HCl}$ at $110^{\circ} \mathrm{C}$ for $24 \mathrm{~h}$. Following pre-column derivatization with $o$-phthaldialdehyde and $N$-isobutyryl-L/D cysteine (IBLC/IBDC), AA enantiomers were measured in hydrolyzates using a High Performance Liquid Chromatography (HPLC) system (1200 series, Agilent, USA). Asx and Glx were used for aspartic acid + asparagine and for glutamic acid + glutamine, respectively, due to the corresponding acids being formed through deamination during hydrolysis. In addition to Asx and Glx, we measured alanine (Ala), arginine (Arg), isoleucine (Ile), leucine (Leu), lysine (Lys), methionine (Met), phenylalanine (Phe), serine (Ser), threonine (Thr), tyrosine (Tyr), and valine (Val). The non-chiral AAs, $\gamma$-aminobutyric acid (GABA) and glycine (Gly), were also measured. The D forms of AAs (D-AAs) generated by acid hydrolysis were calibrated according to Kaiser and Benner (2005).

Phytoplankton pigments were extracted with $\mathrm{N}, \mathrm{N}-$ dimethylformamide and analyzed using an HPLC system (1100 series: Agilent, USA), following a modified version of the method of Mantoura and Llewellyn (1983) and Van Heukelem and Thomas (2001). Solvent A was methanol and $1 \mathrm{~mol} \mathrm{~L}^{-1}$ ammonium acetate $(80: 20, v / v)$, and solvent $\mathrm{B}$ was pure methanol. A detailed description of the gradient elution procedure is given by Huang et al. (2010). We identified pigments by their retention times and absorption spectra, using a set of 21 pigment standards (chlorophyll $c 3$, chlorophyllide? $a$, chlorophyll $c 1+c 2$, peridinin, $19^{\prime}$-butanoyloxyfucoxanthin, fucoxanthin, neoxanthin, prasinoxanthin, 19'-hexanoyloxyfucoxanthin, violaxanthin, diadinoxanthin, alloxanthin, diatoxanthin, zeaxanthin, lutein, chlorophyll $b$, chlorophyll $a, \beta, \varepsilon$-carotene, $\beta, \beta$-carotene, pheophorbide a, and pheophytin a) obtained from DHI (Denmark).

Following the removal of inorganic carbon with $\mathrm{HCl}$ vapor (Wu et al., 2013), POC and PN were measured with an elemental analyzer (Vario EL III: Germany). The detection limits for carbon and nitrogen were 7.5 and $8.0 \mu \mathrm{g}$, respectively, 
with a precision better than $6 \%$. We measured $\delta^{13} \mathrm{C}$ samples using an isotope-ratio mass spectrometer (Deltaplus XP: Thermo Finnigan, USA) connected to a Flash EA 1112 analyzer. The ${ }^{13} \mathrm{C} /{ }^{12} \mathrm{C}$ is expressed in per mil relative to the VPDB standard using the conventional $\delta$ notation. DOC samples were measured with a TOC analyzer (TOC-L $\mathrm{LPH}_{\mathrm{CP}}$ : Shimadzu, Japan), whereas ammonium was measured manually using the sodium hypobromite oxidation method, with an analytical precision of $0.04 \mu \mathrm{M}$. The other four nutrients were measured using an auto-analyzer (AA3: SEAL Analytical, USA), with the precisions of nitrate, nitrite, dissolved inorganic phosphorus (DIP, $\left.\mathrm{PO}_{4}^{3-}\right)$, and silicate $\left(\mathrm{SiO}_{3}^{2-}\right)$ being $0.01,0.003,0.005$, and $0.02 \mu \mathrm{M}$, respectively. The concentration of total suspended matter (TSM) was determined from POC samples (i.e., GF/F filters).

\subsection{Data processing and flux estimate}

We applied CHEMTAX to the phytoplankton pigment data set to estimate the structure of phytoplankton communities (Mackey et al., 1996). To avoid apparent changes in diagnostic pigment ratios, we avoided riverine samples and focused solely on samples from the fjord surface (Mackey et al., 1997). Based on our observations and those of previous workers (Not et al., 2005; Piquet et al., 2014; Schulz et al., 2013), the phytoplankton groups analyzed in this study include diatoms, cryptophytes, prasinophytes, dinoflagellates, haptophytes (e.g., Emiliania Hay and Mohler, Phaeocystis Lagerheim), chlorophytes, cyanobacteria (e.g., Synechococcus), and chrysophytes. Initial ratios are similar to the values reported by Not et al. (2005) for a neighboring study area. Finally, we present ratio data from a single CHEMTAX run, as our attempt at ratio-iteration (Latasa, 2007) produced anomalous results.

We note that the taxonomic terms are operationally defined based on the composition of the diagnostic pigments. Therefore, "chlorophytes" includes both chlorophytes and prasinophytes lacking prasinoxanthin. Similarly, "diatoms" may include both diatoms and some haptophytes and chrysophytes with a similar pigment composition. "Haptophytes" refers to the specific type of algae with both 19 'hexanoyloxyfucoxanthin and fucoxanthin; e.g., Emiliania and Phaeocystis, which have been found in previous studies of Kongsfjorden (Piquet et al., 2014).

The degradation index (DI) was derived from the THPAA data set developed by Dauwer and Middelburg (1998) and later modified by Vandewiele et al. (2009):

$\mathrm{DI}=\sum_{i}\left(\frac{\operatorname{var}_{i}-{\mathrm{AVG} \operatorname{var}_{i}}_{i}}{\mathrm{SD} \operatorname{var}_{i}}\right) \times$ fac.coef. $_{i}$

where $\operatorname{var}_{i}$, AVG var $i$, SD var $i$, and fac.coef. ${ }_{i}$ are the mol \%, mean, standard deviation, and factor score coefficient of amino acid $i$, respectively. Factor score coefficients were calculated using principal component analysis and were directly cited from the literature (Vandewiele et al., 2009). The index ranges from +1 for phytoplankton/bacteria to -1.5 for highly degraded oxic sediments.

For Bayelva River materials flux estimate, it is calculated as materials concentration during our observation at NVE station (in $\mathrm{mg} \mathrm{L}^{-1}$ ) multiplied by the 2012 annual river discharge volume (in $\mathrm{m}^{3}$ ). At the NVE station, river water is free of tide influence and the tide effect is not considered in the flux discussion. For whole Svalbard POC flux estimate, we use our own POC content (at NVE station, in \%) multiplied by the whole Svalbard TSM flux (cited from literature, in tons). For whole Svalbard DOC flux estimate, we use DOC concentration in our study (at NVE station, in $\mathrm{mg} \mathrm{L}^{-1}$ ) multiplied by annual runoff of the whole of Svalbard (cited from literature, in $\mathrm{km}^{3}$ ). The error for flux estimate is calculated as half of the standard deviation of DOC (or POC) multiplied by discharge. The area-weighted flux and dischargeweighted flux is the flux divided by glacier area $\left(\mathrm{in}^{2} \mathrm{~km}^{2}\right.$ ) and annual runoff (in $\mathrm{km}^{3}$ ), respectively.

\section{Results}

Reflecting the considerable turbidity of the Bayelva River, we recorded TSM concentrations of up to $345 \mathrm{mg} \mathrm{L}^{-1}$ at the NVE station (Table 1) and as high as $740 \mathrm{mg} \mathrm{L}^{-1}$ at the BC station (Fig. 1b). Mean riverine POC at NVE station was $56 \mu \mathrm{M}$, while the POC content in TSM (i.e., POC\%) averaged $0.35 \%$ (Table 1). Particulate AAs at the NVE station were low, with an average value of $1 \mu \mathrm{M}$ (Table 1). Also at the NVE station, D-AAs averaged $42 \mathrm{nM}$ (Table 1) and the proportion of D-AAs in THPAA was $4.0 \%$. While trace amounts of several pigments were measured in the river, chlorophyll $a$ (Chl $a$ ) was the dominant pigment, with a mean concentration at NVE station of $0.26 \mu \mathrm{gL}^{-1}$ (Table 1). In contrast, the principal diagnostic riverine pigment, fucoxanthin, gave a mean value at NVE station of $54 \mathrm{ng} \mathrm{L}^{-1}$. Over the course of our observation, DOC concentrations at NVE station ranged from 20.8 to $97.8 \mu \mathrm{M}$, with a mean value of $73 \mu \mathrm{M}$ (Table 1). In 2012, the annual water discharge of the Bayelva River was $29 \times 10^{6} \mathrm{~m}^{3}$ according to the hourly-averaged instrumental record.

In Kongsfjorden, surface concentrations of TSM, POC, and THPAA generally decreased from the eastern end, where tidewater glaciers enter the sea, to the open western end. We identified an additional area of high concentration close to the Bayelva River mouth (Fig. 2a-c). The POC\% of surface water averaged $1.3 \%$ in the marine sectors (i.e., $S>30$ ) of the fjord, and POC\% of all the surface fjord samples averaged $1.1 \%$ (i.e., $S>0$ ), but it fell to $0.62 \%$ in near-bottom water (Table 1). In comparison, the mean POC\% of Bayelva River (e.g., at NVE station) water was $0.35 \%$ (Table 1). $\Delta \delta^{13} \mathrm{C}$ values of samples from the Bayelva River NVE station, the fjord surface, and near-bottom fjord water averaged -23.9 , -24.6 , and $-24.5 \%$, respectively (Table 1 ). The distribu- 


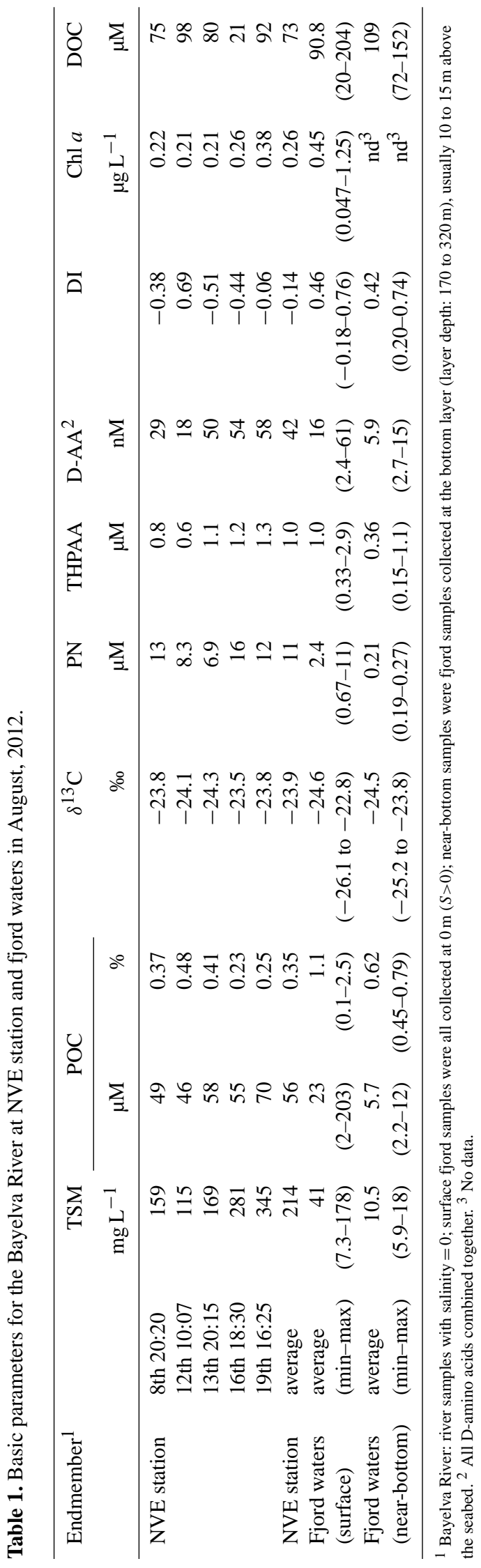

tion of PN was similar to that of POC, with the PN content in TSM (PN\%) in water being comparable. The mean PN\% of samples from the fjord surface, near-bottom, and Bayelva River was $0.17,0.06$, and $0.07 \%$, respectively. Not only was the DI of fjord surface water (0.46) higher than that of river water $(-0.14)$ (Table 1), we also observed elevated DI values (e.g., 0.76 at station 6\#) in the western part of the fjord, where high concentrations of $\mathrm{Chl} a$ and chlorophyllide a occurred (Fig. 2d, e). The DI value of near-bottom water was 0.42 (Table 1). D-AAs were higher in concentration in glacier meltwater (i.e., Bayelva River) when compared to both fjord surface and near-bottom water (i.e., $42 \mathrm{nM}$ vs. 16 and $5.9 \mathrm{nM}$; Table 1). The proportion of D-AAs in the fjord surface water $(1.6 \%)$ was lower than that of the Bayelva River $(4.7 \%)$ and of near-bottom water (1.8\%), whereas levels of the nonprotein AA, GABA, averaged $0.92 \mathrm{nM}$ in fjord surface water and $2.6 \mathrm{nM}$ in the Bayelva River. GABA was most depleted in the near-bottom water (mean value of $0.49 \mathrm{nM}$ ).

A clear difference existed in the concentration of dissolved nutrients among respective regions/sources. For example, both the river water and floating glacier-derived ice were depleted in nutrients, whereas high concentrations of nutrients occurred in the near-bottom water of Kongsfjorden, beneath the pycnocline (Table 2). Despite this disparity in concentration, nitrate was the main form of dissolved inorganic nitrogen (DIN) in both the river water and the fjord near-bottom water (Table 2).

Cyanobacteria, chrysophytes, and dinoflagellates occurred only in trace amounts in the fjord surface water, where diatoms were the primary contributor to the total fjord phytoplankton biomass (i.e., $\mathrm{Chl} a$ ), followed by cryptophytes. On average, diatoms contributed half of the total phytoplankton biomass, with cryptophytes contributing another $28 \%$ (Table 3). In western and middle parts of the fjord, diatoms were dominant, whereas in other regions there was a greater contribution from tiny cryptophytes. For example, at stations 14\# and 15\# (Fig. 1a), cryptophytes accounted for 40 and $48 \%$ of the total $\mathrm{Chl} a$, respectively.

\section{Discussion}

\subsection{POM composition and implications}

\subsubsection{Bacterial influence on amino acid enantiomers and its contribution to POM}

Bacteria plays an important role in organic matter composition (Rokkan Iversen and Seuthe, 2011). In a study at two other marine sites (BATS and HOTS) at lower latitudes, Kaiser and Benner (2008) suggested that $12-32 \%$ of the POC and 20-64\% of the PN were derived from bacteria. In Kongsfjorden, bacterial contributions to POC and PN can also be estimated. Here, we exploited the universal distribution of D-Ala in bacteria to calculate the amounts of bacterial 


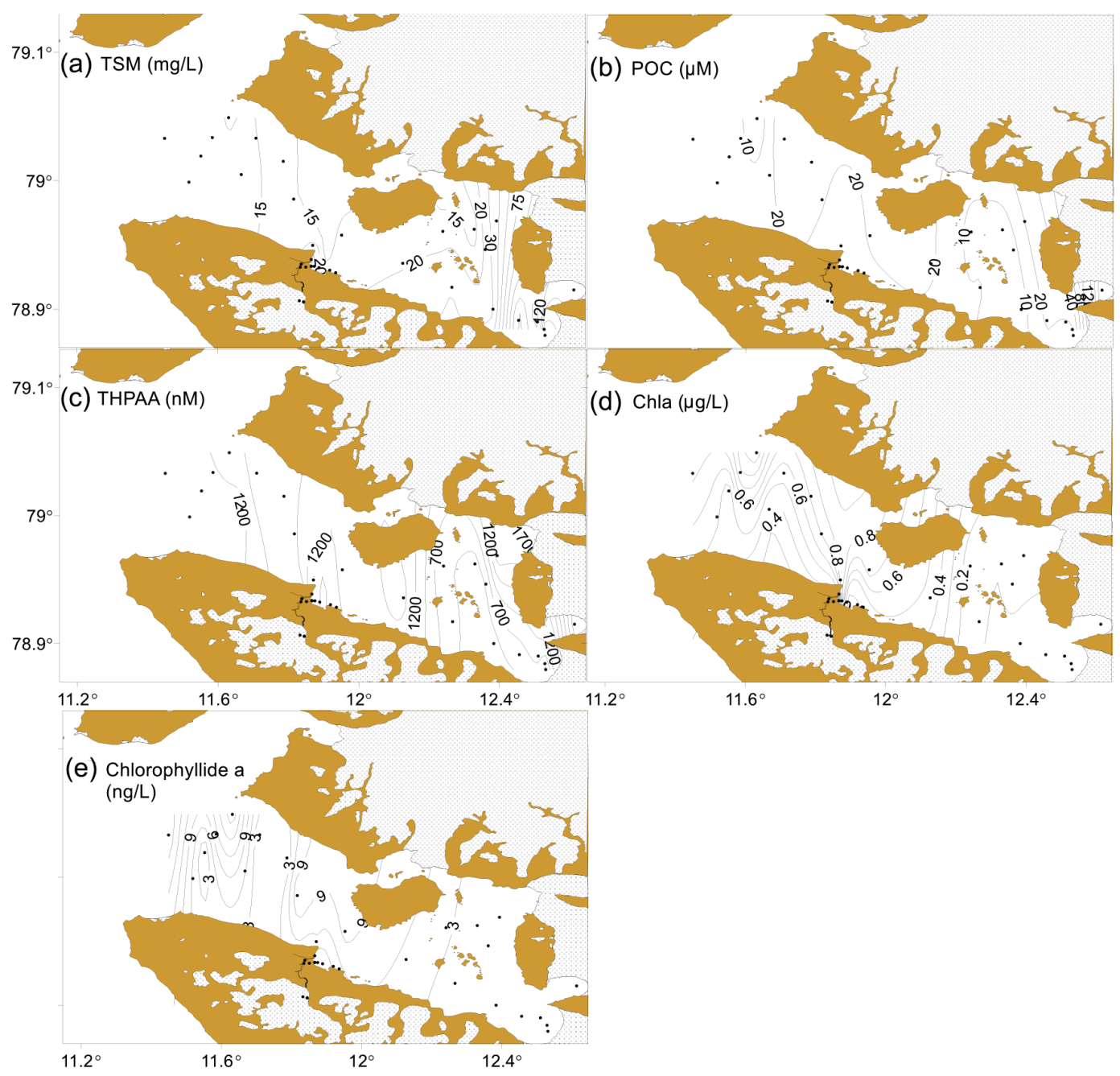

Figure 2. Surface (a) total suspended matter (TSM), (b) particulate organic carbon (POC), (c) total hydrolyzable particulate amino acids (THPAA), (d) chlorophyll $a$ (Chl $a$ ) and (e) chlorophyllide $a$ distribution in the Kongsfjorden.

Table 2. Dissolved inorganic nutrients (mean (min-max)) in this study (unit: $\mu \mathrm{M})$.

\begin{tabular}{lrrrrr}
\hline Endmember & $\mathrm{NH}_{4}^{+}$ & $\mathrm{NO}_{2}^{-}$ & $\mathrm{NO}_{3}^{-}$ & $\mathrm{SiO}_{3}^{2-}$ & $\mathrm{PO}_{4}^{3-}$ \\
\hline Bayelva River & 0.28 & 0.05 & 2.87 & 5.68 & 0.06 \\
& $(0.18-0.42)$ & $(0.02-0.1)$ & $(0.62-5.65)$ & $(3.73-6.88)$ & $(0.04-0.13)$ \\
Floating ice & 0.33 & 0.003 & 0.20 & 0.08 & 0.02 \\
& $(0.23-0.44)$ & $\left(\mathrm{bdl}^{1}-0.01\right)$ & $(0.03-0.43)$ & $\left(\mathrm{bdl}^{1}-0.13\right)$ & $(0.01-0.03)$ \\
Fjord waters & 0.76 & 0.059 & 0.6 & 1.74 & 0.05 \\
(surface) & $(0.18-2.2)$ & $\left(\mathrm{bdl}^{1}-0.17\right)$ & $(0.01-2.32)$ & $(0.56-6.07)$ & $(0.01-0.26)$ \\
Fjord waters & 1.65 & 0.3 & 7.88 & 3.85 & 0.66 \\
(near-bottom) & $(1.07-2.45)$ & $(0.2-0.43)$ & $(4.95-9.44)$ & $(1.95-5.51)$ & $(0.49-0.76)$ \\
\hline
\end{tabular}

${ }^{1}$ Below detection limit. ${ }^{2}$ Floating ice: clean floating ice in the fjord; the other endmembers are as described in Table 1.

organic carbon and nitrogen. Additionally, considering the potential differences between riverine and marine bacterial community structures, we estimated bacterial contributions for both riverine and marine samples (Table 4). For riverine samples (i.e., $S=0$ ), we used only freshwater culture data from Table 2 of Kaiser and Benner (2008) for the D-Ala converting factor, whereas for marine samples (i.e., $S>30$ ) the D-Ala converting factor is based solely on marine bacteria 
Table 3. Phytoplankton groups contributions to total Chl $a$ estimated via CHEMTAX (unit: \%).

\begin{tabular}{lrrr}
\hline Group & Average & Min & Max \\
\hline Diatoms & 50 & 6.6 & 78 \\
Cryptophytes & 28 & 5.9 & 48 \\
Prasinophytes & 11 & 4.5 & 17 \\
Chlorophytes & 4.3 & 0 & 17 \\
Haptophytes & 3.8 & 0 & 9.5 \\
Dinoflagellates & 3.1 & 0 & 7.3 \\
Chrysophytes & 0.5 & 0 & 2 \\
Cyanobacteria & 0.2 & 0 & 2.2 \\
\hline
\end{tabular}

Table 4. Bacteria-contributed $\mathrm{POC}$ and $\mathrm{PN}$ proportion relative to bulk POC and PN (in \%) derived from D-Ala concentrations ${ }^{1}$.

\begin{tabular}{|c|c|c|}
\hline Region $^{2}$ & Bacterial POC\% & Bacterial PN\% \\
\hline Bayelva & $13=$ & \\
\hline Marine & $19 \pm 9.5$ & $36 \pm 18$ \\
\hline \multicolumn{3}{|c|}{$\begin{array}{l}{ }^{1} \text { Terrestrial bacteria D-Ala content: } 108 \mathrm{nmol} \mathrm{mg}{ }^{-1} \mathrm{C} \text {, marine } \\
\text { bacteria D-Ala content: } 50.3 \mathrm{nmol} \mathrm{mg} \mathrm{m}^{-1} \mathrm{C}, 215 \mathrm{nmol} \mathrm{mg}^{-1} \mathrm{~N} \text {. The } \\
\text { value is derived/cited from literature (Kaiser and Benner, 2008). } \\
{ }^{2} \text { Bayelva River used all the samples with } S=0 \text { and marine } \\
\text { samples only used samples in the Kongsfjorden with } S>30 \text {. }\end{array}$} \\
\hline
\end{tabular}

(Kaiser and Benner, 2008). Note that the D-Ala-based estimates would also include contribution of any non-living detritus that contained D-Ala.

In Kongsfjorden, the bacterial contribution to POC (19\%; Table 4) was well within the value reported by Rokkan Iversen and Seuthe (2011) based on the cell density and conversion factor approach, and it was similar to values reported for other marine regions at lower latitudes (Kaiser and Benner, 2008). The bacterial contribution to POC was slightly lower $(13 \%)$ in the Bayelva River than that in the fjord (i.e., $19 \%$ ). With respect to nitrogen, the bacterial contribution accounted for $36 \%$ of PN in fjord water (Table 4 ).

Given that D-Ala occurs widely in biopolymers, whereas D-Glx is present in relatively few bacterial compounds, the overall D-Ala/D-Glx ratio would become $>1$ (Kaiser and Benner, 2008 and ref. therein). Both the riverine $(r=0.83$, $p=0.006, n=9)$ and fjord $(r=0.95, p<0.001, n=31) \mathrm{D}$ Ala levels were strongly related to their respective D-Glx levels, exhibiting almost identical slopes (river: 1.26, fjord: 1.21; Fig. 4). The D-Ala/D-Glx slopes in both the river and the fjord (i.e., 1.26 and 1.21, respectively; Fig. 4) are comparable to the reported D-Ala/D-Glx value of $1.3 \pm 0.4$ (Kaiser and Benner, 2008), which was derived from a pure bacteria culture that included both marine/fresh and heterotrophic/autotrophic bacteria. Given that Glx has a higher abiotic racemization rate than Ala (Wehmiller et al., 2012), the slightly higher D-Ala/D-Glx slope for river samples relative to fjord samples (i.e., 1.26 vs. 1.21; Fig. 4) indicates that D-AAs in riverine suspended particles likely originate

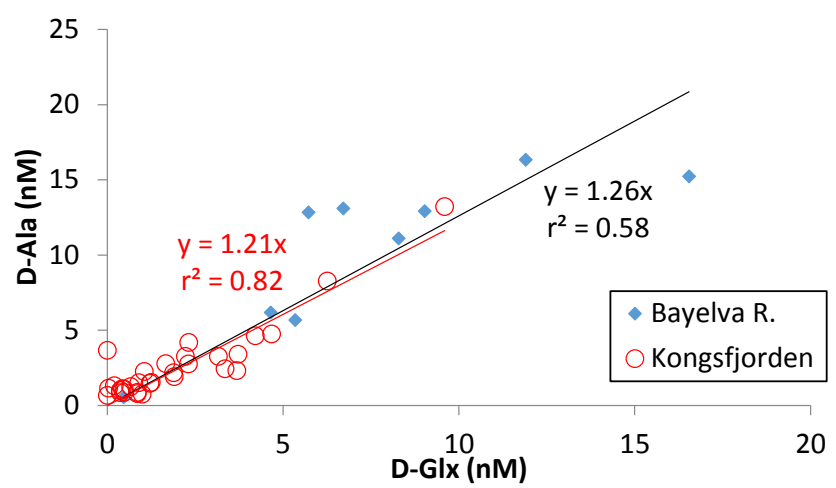

Figure 3. D-Ala plotted against D-Glx for both river $(S=0)$ and fjord $(S>0)$ suspended particulate samples.

from a modern contribution (e.g., bacteria) rather than abiotic racemization in the river basin. The presence of bacteria and their modification of organic matter $(\mathrm{OM})$ in both subglacial (Sharp et al., 1999) and supraglacial (Anesio et al., 2010) regions have been confirmed in previous studies. As for the Bayelva River basin, previous hydrochemical data (e.g., $\mathrm{NO}_{3}^{-} / \mathrm{Cl}^{-}$) also indicated that there is a nitrification process in the soils that contributes to riverine nutrients (Hodson et al., 2002), and hence the presence of bacteria.

\subsubsection{In situ POM assimilation in Kongsfjorden}

The contribution of AAs to the total carbon and nitrogen budgets reflects the freshness of POM (Davis et al., 2009). Using our measurements of THPAA, we calculated AA carbon and nitrogen amounts, and normalized the results against bulk $\mathrm{POC}$ and $\mathrm{PN}$, respectively (i.e., $\mathrm{POC}_{\mathrm{AAs}} / \mathrm{POC}$ and $\mathrm{PN}_{\mathrm{AAs}} / \mathrm{PN}$, in \%). For the turbid glacier meltwater, phytoplankton pigments are depleted (Table 1) and on average AAs account for $7 \%$ of the riverine POC and $11 \%$ of the riverine PN (Fig. 3a). In contrast, the $\mathrm{PN}_{\mathrm{AAs}} / \mathrm{PN}$ of Kongsfjorden is as high as $90 \%$, with an average of $78 \%$ (Fig. 3a). With the exception of one outlier, Chl $a / \mathrm{POC}$ values rise gradually from glacier meltwater to the fjord surface water (Fig. 3a), suggesting an increasing contribution from in situ POM production.

In the case that other obvious sources of protein and AAs are negligible, we attribute the increasing $\mathrm{PN}_{\mathrm{AAs}} / \mathrm{PN}$ in the fjord (i.e., samples with $S>0$ ) to the in situ assimilation of ambient nitrogen via autotrophs (e.g., phytoplankton) and further transfer within the food web (PN $\mathrm{PN}_{\mathrm{AAs}} / \mathrm{PN}$ vs. Chl $a$ : $r=0.49, p=0.01, n=25$; Fig. 3b). As glacier meltwater is rich in TSM (Fig. 2a; Table 1), the observed distribution of POM composition suggests that light is a limiting factor for $\mathrm{OM}$ assimilation in the fjord surface water (i.e., $\mathrm{PN}_{\mathrm{AAs}} / \mathrm{PN}$ vs. TSM: $r=-0.79, p<0.001, n=25$; figure not shown). However, since the fjord is also characterized by a very low N/P ratio, as confirmed by our data (the mean N / P ratio in fjord surface water is 7.7), nitrogen could be another 

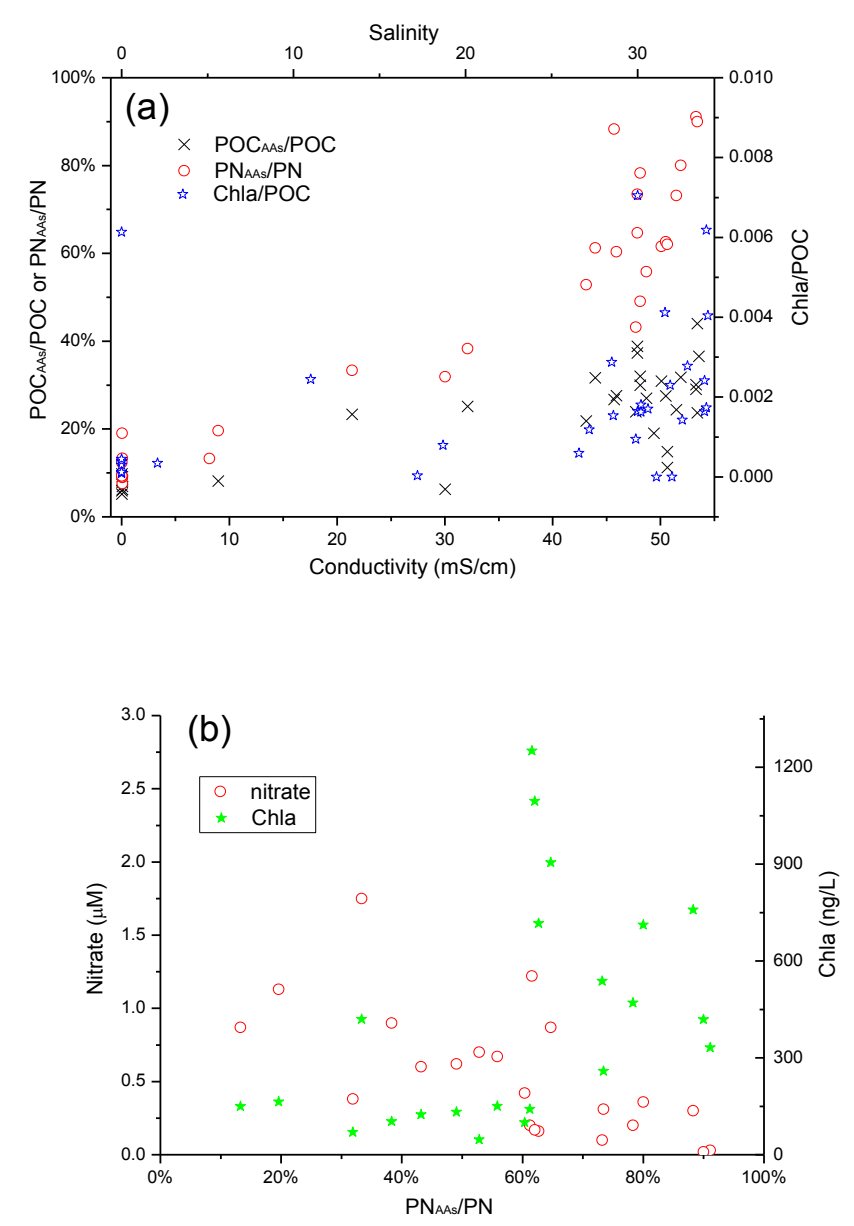

Figure 4. THPAA contribution to carbon and nitrogen: (a) along with salinity in the surface waters from glacier meltwater to the Kongsfjorden; (b) its relations with nitrate and Chl $a$ for fjord samples only (i.e., $S>0$ ).

limiting factor for primary production (Rokkan Iversen and Seuthe, 2011). This effect is suggested by the distribution of POM composition when plotted against nitrate $\left(\mathrm{PN}_{\mathrm{AAs}} / \mathrm{PN}\right.$ vs. nitrate: $r=-0.72, p<0.001, n=25$; Fig. $3 b$ ). However, $\mathrm{PN}_{\mathrm{AAs}} / \mathrm{PN}$ is not related to ammonium or nitrite (figure not shown).

Although ammonium is typically the preferred nitrogen nutrient for phytoplankton, we found nitrate, rather than ammonium, to be coupled with POM assimilation in Kongsfjorden (Fig. 3b). As glacier meltwater is depleted in nutrients relative to fjord water (Table 2), the seaward dilution effect on nitrate is expected to play a minor role in the coupling between nitrate and POM assimilation (Fig. 3b). Instead, surface-water ammonium originates primarily from zooplankton, which exerts grazing pressure on phytoplankton and also leads to increased $\mathrm{PN}_{\mathrm{AAs}} / \mathrm{PN}$ (Fig. 3b). Also, as estimated by CHEMTAX (Table 3), diatoms are the principal phytoplankton group, particularly in open-fjord environments such as western Kongsfjorden. Previous work, us- ing cultured diatoms preconditioned for nitrate, has shown that ammonium uptake in diatoms can be inhibited by nitrate (Dortch and Conway, 1984). In Kongsfjorden, inflowing Atlantic water masses are the main source of nutrients for phytoplankton (Hegseth and Tverberg, 2013). Therefore, since nitrate was the main form of DIN in Atlantic water (Table 2), it is possible that the presence of diatoms in the fjord induced (or enhanced) the nitrate limitation during OM assimilation (Fig. 3b).

Although the proportion of proteins and AAs in total-cell nitrogen varies (due to algae physiological status and intergroup phytoplankton differences), proteins, together with AAs, constitute the primary form of phytoplankton nitrogen and on average account for $70 \%$ of total algal cellular nitrogen (Dortch et al., 1984). By employing an algal POC : Chl $a$ ratio of 50 (Hop et al., 2002) and a Redfield ratio of 6.6 (Redfield et al., 1963), it is possible to estimate the contribution of phytoplankton THPAA nitrogen to PN via observed Chl $a$ concentration. For Kongsfjorden, we estimate the phytoplankton contribution as $14 \%$. As the calculation was based on Chl $a$, so the term phytoplankton here includes both algae and any other detritus/matters that contains Chl $a$.

On average, THPAA nitrogen accounted for $78 \%$ of the fjord PN (Fig. 3a), given that bacteria THPAA nitrogen contributed $36 \%$ of the PN (Table 4) and phytoplankton contributed another $14 \%$, so there is $28 \%$ of the THPAA nitrogen contribution unaccounted for. We suggest that this inconsistency results from uncertainty and limitation in the above estimates and from the detritus that were free of both $\mathrm{D}$ Ala and Chl $a$. The samples with $\mathrm{PN}_{\mathrm{AAs}} / \mathrm{PN}>70 \%$, however, were all obtained from the open western end of the fjord, where zooplankton are abundant (Hop et al., 2006), and we also observed abundant zooplankton during filtration. Though zooplankton were manually removed during filtration, their detritus can hardly be avoided, which can be free of D-Ala and Chl $a$. Due to their similar compositional distribution among different lives, amino acid composition can rarely be used to distinguish the respective contributions of phytoplankton, bacteria, and zooplankton (Cowie and Hedges, 1992). Degraded chlorophyll (e.g., chlorophyllide $a$ ), however, showed elevated concentrations at the western end of the fjord (Fig. 2e), suggesting that grazing pressure was heavier there (Hop et al., 2002). Therefore, for samples with extremely high $(>70 \%) \mathrm{PN}_{\mathrm{AAs}} / \mathrm{PN}$ value, it is likely that the detritus, probably derived from zooplankton, played an important role in modifying the composition of POM. In doing so, the zooplankton detritus contribution to $\mathrm{PN}$ is comparable to that of phytoplankton and bacteria (i.e., $28 \%$ vs. 14 and $36 \%)$.

\subsection{Organic matter flux estimate}

Along the Bayelva River (i.e., from the glacier terminus BC station to NVE station, Fig. 1b), clear decrease of TSM and POC was identified. The TSM decreased from $741 \mathrm{mg} \mathrm{L}^{-1}$ 
at the BC station to $214 \mathrm{mg} \mathrm{L}^{-1}$ at NVE station and correspondingly the POC decreased from around 102 to $56 \mu \mathrm{M}$. In the meantime, the DOC decreased from $167 \mu \mathrm{M}$ at the $\mathrm{BC}$ station to $73 \mu \mathrm{M}$ at NVE station. The ice marginal and proglacial environments are important zones of ion acquisition in melt water and an increasing trend of major ion concentration in meltwater can be found downstream along the river (Hodson et al., 2002). In this work, we found the conductivity of the meltwater increased from $29.8 \mu \mathrm{S} \mathrm{cm}^{-1}$ (BC station) to $74.8 \mu \mathrm{S} \mathrm{cm}^{-1}$ (NVE station), which also indicates the ion acquisition in the ice marginal/proglacial region. Given the increase of conductivity, the decrease of organic matter may be due to a flocculation process in the water column and also the desorption/adsorption balance difference along the river. The decreasing trend of suspended parameters along Bayelva River agreed well with the previous findings that the proglacial sandur is a major net suspended sediment sink throughout most time of the melt season (Hodson et al., 1998) and we further propose that it can also greatly impact DOC as a clear DOC decrease was observed.

The annual water discharge of the Bayelva River in $2012\left(29 \times 10^{6} \mathrm{~m}^{3}\right)$ was relatively low compared with levels recorded between 1990 and $2001\left(\sim 27 \times 10^{6}\right.$ to more than $40 \times 10^{6} \mathrm{~m}^{3}$ ) (Bogen and Bønsnes, 2003). Seasonally, some studies of glacier meltwater flux reported no clear temporal variability in the concentration of suspended particles over the course of the melt season (Bhatia et al., 2013), but other study suggests that highest TSM concentrations often occur late in the melt season, and that rain floods, instead of snowmelt, can cause the high concentrations (Bogen and Bønsnes, 2003). Inter-annually, sediment flux in the Bayelva River showed large variation, ranging from 5126 to 22797 tons year $^{-1}$ (Bogen and Bønsnes, 2003) over a 12year observation. All these previous studies indicate the complexity of TSM concentration variation in glacier meltwater. During our observation, TSM, POC, and DOC concentrations at NVE station (Table 1) showed no relation with water discharge at the sampling day nor at the sampling hour (data not shown). As an estimate, we calculated the flux based on the discharge data and results from the NVE station (Table 1). Bayelva River fluxes of TSM, POC, DOC, and PN in 2012 are estimated to be $6400 \pm 1300,20 \pm 1.6,25 \pm 5.6$, and $4.7 \pm 0.75$ tons year $^{-1}$, respectively. And our estimated POC flux for the Bayelva River is very close to a previous estimate $\left(22 \pm 3\right.$ tons year $\left.^{-1}\right)$ for the 2011 ablation season (Kuliñski et al., 2014).

There are many meltwater rivers/creeks on Svalbard, and a comprehensive study to their organic carbon concentrations is not available. However, previous meltwater organic carbon study reveals that DOC in the meltwater rivers ranged from 165-426 $\mu \mathrm{M}$ (Stibal et al., 2008; Tye and Heaton, 2007), while POC content in common meltwater rivers is about $0.5 \%$ (Kuliñski et al., 2014). DOC concentration in our study (Table 1) is lower when compared to these values, but POC content is very comparable to previous values (i.e., $0.35 \%$ vs.
$0.5 \%$ ). Further, the glacier coverage in Bayelva River basin is $55 \%$ (Bogen and Bønsnes, 2003), the same as the whole Svalbard, whose glacier coverage is also $55 \%$ (Lang et al., 2015). So the Bayelva River alone can hardly represent the whole Svalbard glacier meltwater rivers in a $100 \%$ manner, but at least it enables the assessment, and the estimated flux is likely to be lower than the true value, given that its DOC and POC concentrations are lower when compared to other glacier meltwater.

Given that the POC\% in TSM is $0.35 \%$ (Table 1) and that the TSM flux for Svalbard is $16 \times 10^{6}$ tons year $^{-1}$ (Hasholt et al., 2006), we estimate that the POC flux for all of Svalbard is $0.056 \pm 0.02 \times 10^{6}$ tons year $^{-1}$ (Table 5). Moreover, by incorporating the total surface runoff $\left(25 \mathrm{~km}^{3}\right.$ year $\left.^{-1}\right)$ from Svalbard's glaciers due to melting of snow and ice (Hagen et al., 2003) and the DOC content of glacier meltwater (Table 1), we estimate the DOC flux for Svalbard to be $0.02 \pm 0.01 \times 10^{6}$ tons year $^{-1}$ (Table 5). The POC flux of Svalbard is equivalent to only $6 \%$ of that from the Greenland Ice Sheet $\left(0.9-0.94 \times 10^{6}\right.$ tons year $\left.^{-1}\right)$ (Bhatia et al., 2013; Lawson et al., 2014), and is significantly smaller than the POC flux of the Mackenzie River (1.8-2.1 × $10^{6}$ tons year $\left.^{-1}\right)$ (Dittmar and Kattner, 2003). However, in terms of DOC flux, the value from Svalbard is $13-25 \%$ that of the Greenland Ice Sheet $(0.08-$ $0.15 \times 10^{6}$ tons year $^{-1}$ ) (Bhatia et al., 2013; Lawson et al., 2014). In comparison, DOC fluxes from glaciers in the Gulf of Alaska and from the small Arctic Yana River and the Mackenzie River are $0.13 \times 10^{6}, 0.09 \times 10^{6}$, and $1.4 \times 10^{6}$ tons year $^{-1}$, respectively (Dittmar and Kattner, 2003; Holmes et al., 2012).

The glacier area on Svalbard is $36600 \mathrm{~km}^{2}$ (Hagen et al., 2003) and the total surface runoff is $25 \mathrm{~km}^{3}$ year (Hagen et al., 2003), resulting in area-weighted fluxes of POC and DOC of 1.5 and 0.55 tons $\mathrm{km}^{-2}$ year $^{-1}$, respectively, and discharge-weighted fluxes of POC and DOC of 2.2 and $0.86 \mathrm{mg} \mathrm{L}^{-1}$, respectively, (Table 5). The areaweighted fluxes of Svalbard are comparable to those of glaciers in the Gulf of Alaska (Table 5) and the Mackenzie River (0.82 tons $\mathrm{km}^{-2}$ year $^{-1}$ ) (Holmes et al., 2012) and are much higher than those of the Greenland Ice Sheet, considering its area of $1200000 \mathrm{~km}^{2}$ (Rignot and Kanagaratnam, 2006) (e.g., for POC: 1.5 tons $\mathrm{km}^{-2}$ year $^{-1}$ vs. $0.7-0.8$ tons $\mathrm{km}^{-2}$ year $^{-1}$; for DOC: 0.55 vs. $0.07-$ 0.12 tons $\mathrm{km}^{-2}$ year $^{-1}$ Table 5). The singular Greenland Ice Sheet is considerably greater in both area and thickness (> $2000 \mathrm{~m}$ ) than small glaciers in Svalbard and Alaska (Hood et al., 2009), which comprise small, relatively thin glaciers. The vast central part of the Greenland Ice Sheet can hardly contribute to the runoff materials flux and hence the different thermal regimes may be the reason for the much lower areaweighted fluxes of the Greenland Ice Sheet, when compared to the other two Svalbard and Alaska glaciers (Table 5).

With respect to the DOC flux, the Svalbard glaciers become important among the pan-Arctic glaciers especially 
Table 5. Estimated organic carbon flux from Svalbard and its comparison with other pan-Arctic glacier systems.

\begin{tabular}{|c|c|c|c|c|c|c|}
\hline & $\begin{array}{r}\text { Total POC } \\
\text { flux }\end{array}$ & $\begin{array}{r}\text { Total DOC } \\
\text { flux }\end{array}$ & $\begin{array}{r}\text { Area-weighted } \\
\text { POC flux }\end{array}$ & $\begin{array}{r}\text { Area-weighted } \\
\text { DOC flux }\end{array}$ & $\begin{array}{r}\text { Discharge-weighted } \\
\text { POC flux }\end{array}$ & $\begin{array}{r}\text { Discharge-weighted } \\
\text { DOC flux }\end{array}$ \\
\hline & $10^{6}$ tons year $^{-1}$ & $10^{6}$ tons year $^{-1}$ & tons $\mathrm{km}^{-2}$ year $^{-1}$ & tons $\mathrm{km}^{-2}$ year $^{-1}$ & $\mathrm{mgL}^{-1}$ & $\mathrm{mg} \mathrm{L}^{-1}$ \\
\hline Svalbard Archipelago & $0.056 \pm 0.02$ & $0.02 \pm 0.01$ & $1.5 \pm 0.5$ & $0.55 \pm 0.3$ & 2.2 & 0.86 \\
\hline Greenland Ice Sheet $^{1}$ & $0.9-0.94$ & $0.08-0.15$ & $0.7-0.8$ & $0.07-0.12$ & 3.7 & 0.32 \\
\hline Gulf of Alaska ${ }^{2}$ & & $0.10 \pm 0.01$ & & $1.3 \pm 0.11$ & & 0.31 \\
\hline
\end{tabular}

${ }^{1}$ Derived from Bhatia et al. (2013) and Lawson et al. (2014). ${ }^{2}$ Derived from Hood et al. (2009).

when the discharge-weighted flux is considered (Table 5). The discharge-weighted flux of DOC of Svalbard is over twice as high than that of the Greenland Ice Sheet and glaciers in the Gulf of Alaska. As reported by Bhatia et al. (2013), DOC from Greenland Ice Sheet showed temporal variability throughout the melt season, yet DOC concentration in glacier meltwater typically remains depleted $(\sim 27 \mu \mathrm{M})$ during the peak melt season. In the turbid Bayelva River, however, although DOC measured at the NVE station exhibited variability (Table 1), it was maintained at a much higher level compared with values from the Greenland Ice Sheets. DOC concentration was as much as $167 \mu \mathrm{M}$ at the glacier terminus and remained elevated $(73 \mu \mathrm{M})$ even as far as the NVE station (Table 1). Although we cannot assess monthly variability in DOC in this study, previous work in neighboring drainage basins suggests that DOC concentration in Svalbard glacial meltwater remains at high levels $(250-426 \mu \mathrm{M}$ in glaciated basins and $165-204 \mu \mathrm{M}$ in nonglaciated basins) between mid-June and early September (Tye and Heaton, 2007). Such high concentrations of DOC in Svalbard glacier meltwater are an important reason for the higher discharge-weighted DOC flux when compared to the other two glaciers (Table 5). And DOC flux would be even greater had we calculated via the previous monthly DOC concentration (Tye and Heaton, 2007). Compared with glaciers in the Gulf of Alaska, glaciers in Svalbard show 2.8 times higher in discharge-weighted DOC flux, whereas the area-weighted DOC flux was only $42 \%$ of that in the Gulf of Alaska (Table 5). This is explained by the much higher meltwater discharge per unit area yielded by glaciers in the Gulf of Alaska $\left(\sim 61^{\circ} \mathrm{N}\right)$, relative to that of glaciers in Svalbard $\left(76-80^{\circ} \mathrm{N}\right)$. Namely, the area-weighted annual runoff for the glaciers in the Gulf of Alaska is $0.0042 \mathrm{~km}_{\text {year }}{ }^{-1}$ $\left(320 \mathrm{~km}^{3}\right.$ year $^{-1}$ divided by $75300 \mathrm{~km}^{2}$ ) (Hood et al., 2009), whereas the area-weighted annual runoff for the glaciers in Svalbard is only $0.00068 \mathrm{~km}_{\text {year }}{ }^{-1}\left(25 \mathrm{~km}^{3}\right.$ year $^{-1} \mathrm{di}^{-}$ vided by $36600 \mathrm{~km}^{2}$ ). Hence, per unit area, glaciers in the Gulf of Alaska yield 6.2 times higher meltwater in discharge when compared to glaciers in Svalbard (i.e., 0.0042 vs. 0.00068), and this 6.2 times multiple relationship is very close to the multiple relationship between the areaweighted DOC flux and discharge-weighted DOC flux difference between the two glaciers, which is 6.6 times (namely $(0.86 / 0.31) \times(1.3 / 0.55)$, (Table 5)). In other words, glacier meltwater in Alaska is high-in-discharge and low-in-DOCconcentration, whereas glacier meltwater in Svalbard is in the opposite situation, namely low-in-discharge and high-inDOC-concentration. The possible reasons include different temperature and drainage basin organic matter background between the two glacier systems. Higher discharge-weighted DOC flux suggests that Svalbard glaciers have a higher efficiency in generating DOC (or higher in DOC concentration) when compared to other pan-Arctic glacier systems like the Greenland Ice Sheet and glaciers in the Gulf of Alaska (Table 5).

Different from DOC flux, the POC flux of Svalbard glaciers is not as important as other pan-Arctic glaciers, and its discharge-weighted flux of POC is even smaller than that of the Greenland Ice Sheet (i.e., $2.2 \mathrm{mg} \mathrm{L}^{-1}$ vs. $3.7 \mathrm{mg} \mathrm{L}^{-1}$; Table 5). Based on the particulate biomarker analysis, the phytoplankton carbon in the glacier meltwater can be calculated by multiplying the riverine $\mathrm{Chl} a$ concentration with the algal-POC:Chl $a$ ratio of 50 (Hop et al., 2002). Further, given the $\mathrm{AA}$ carbon and nitrogen amount (i.e., $\mathrm{POC}_{\mathrm{AAs}}$ and $\mathrm{PN}_{\mathrm{AAs}}$ ), AA and phytoplankton carbon together accounted for $9.5 \%$ of the POC flux, and nitrogen accounted for $11 \%$ of the PN flux. Assuming that AA and phytoplankton carbon represent the labile POM pool, the labile proportion in the total POM flux will be $\sim 10 \%$ of the total POM flux (i.e., for POC flux, $9.5 \%$; for PN flux, $11 \%$ ). This proportion is comparable to that of the Greenland Ice Sheet POM, in which the labile component is estimated at $9 \%$ using a carbohydrate approach (Lawson et al., 2014). Due to the rapid removal process in the estuarine and adjacent fjord, most glacier meltwater POC is expected to be buried within adjacent fjords (Dittmar and Kattner, 2003).

The manners by which meltwater drains through the glaciers vary in Svalbard (Hodgkins, 1997) and this impacts the meltwater chemistry (Hodson et al., 2002; Wadham et al., 1998). Whether the meltwater flows through supra-, enor sub-glacial channels would have great impact on the nutrients, TSM, and further organic matter in the glacier meltwater. Also, the ice marginal and proglacial environments play an important role in further modifying the organic carbon and nutrients content in glacier meltwater before it enters the sea (Hodson et al., 2002). The TSM in glacier meltwater is one of the few parameters that has been routinely monitored, and the Bayelva River shows a very large annual TSM flux 
variation over a 12-year timescale, with the maximum flux being over four times higher than the minimum flux (i.e., 22797 tons year $^{-1}$ vs. 5126 tons year $^{-1}$; Bogen and Bønsnes, 2003), indicating the complexity in TSM concentration variation (Hasholt et al., 2006). Due to both the asymmetry of the organic carbon flux in a single glacier meltwater river and the heterogeneity among different meltwater drainages, we consider our provisional estimates of Svalbard POC and DOC to be tentative. Long-time monitoring data for organic carbon in Svalbard are not reported so far, and little is known about Svalbard organic carbon flux. The values in Table 5 are preliminary estimates and hence should be viewed with care and more work is needed to improve the estimates of glacier flux. Furthermore, the fluxes reported here are based solely on glacier meltwater runoff data and thus exclude iceberg calving, which accounts for one-sixth of the runoff flux in Svalbard (Hagen et al., 2003). Consequently, the organic carbon flux will need to be further updated when tidewater glacier contribution become available.

\section{Conclusions}

Using AAs and phytoplankton pigments as biomarkers, we elucidated the POM composition in the glacier-fed Bayelva River and adjacent Kongsfjorden. In the glacier meltwater, AAs represent 7 and $11 \%$ of the bulk POC and PN, respectively, whereas in the fjord, AAs nitrogen amount can exceed $90 \%$ of bulk PN, suggesting strong in situ assimilation. Furthermore, AAs indicate that bacteria accounts for 13 and $19 \%$ of the POC in the Bayelva River and Kongsfjorden, respectively. This proportion is even greater for PN, with values of $36 \%$ being determined for the fjord.

The annual flux of terrigenous material in the Bayelva River is estimated at $6400 \pm 1300$ tons for TSM, $20 \pm 1.6$ tons for POC, $25 \pm 5.6$ tons for DOC, and $4.7 \pm 0.75$ tons for PN. Furthermore, annual POC and DOC fluxes for all of Svalbard are estimated to be $0.056 \times 10^{6}$ and $0.02 \times 10^{6}$ tons year $^{-1}$, respectively. Though lower in bulk value, the area-weighted and discharge-weighted organic carbon flux for Svalbard is comparable or even higher compared with other pan-Arctic glacier systems (e.g., the Greenland Ice Sheet and glaciers in the Gulf of Alaska). In particular, the discharge-weighted flux of DOC of Svalbard glaciers is over twice as high than other pan-Arctic glacier systems and hence it is more efficient in DOC output, suggesting its important role as a terrestrial DOC source. Further work is needed to improve our understanding of organic carbon fluxes of the whole Svalbard glacier meltwater.
Acknowledgements. This work was supported by Chinese Arctic and Antarctic Administration (2012YR11011) and SKLEC/ECNU (2011KYYW02), as well as the National Science Foundation of China (41206065). We are grateful to all the team members during our investigation in the Yellow River Station, as well as the staff in Ny-Ålesund, who provided us assistance during our field work. The authors are grateful to their German colleagues, Gerhard Kattner, Boris Koch and Kai Uwe Ludwichowskf, who kindly helped us with establishing the amino acids measurement method in the laboratory. We thank the two anonymous reviewers who provided constructive comments to improve the original manuscript.

Edited by: N. Ohte

\section{References}

Anesio, A. M., Sattler, B., Foreman, C., Telling, J., Hodson, A., Tranter, M., and Psenner, R.: Carbon fluxes through bacterial communities on glacier surfaces, Ann. Glaciol., 51, 32-40, 2010.

Bhatia, M. P., Das, S. B., Xu, L., Charette, M. A., Wadham, J. L., and Kujawinski, E. B.: Organic carbon export from the Greenland ice sheet, Geochim. Cosmochim. Ac., 109, 329-344, 2013.

Bogen, J. and Bønsnes, T. E.: Erosion and sediment transport in High Arctic rivers, Svalbard, Polar Res., 22, 175-189, 2003.

Cowie, G. L. and Hedges, J. I.: Sources and reactivities of amino acids in a coastal marine environment, Limnol. Oceanogr., 37, 703-724, 1992.

Dauwe, B. and Middelburg, J. J.: Amino acids and hexosamines as indicators of organic matter degradation state in North Sea sediments, Limnol. Oceanogr., 43, 782-798, 1998.

Davis, J., Kaiser, K., and Benner, R.: Amino acid and amino sugar yields and compositions as indicators of dissolved organic matter diagenesis, Org. Geochem., 40, 343-352, 2009.

Dittmar, T. and Kattner, G.: The biogeochemistry of the river and shelf ecosystem of the Arctic Ocean: a review, Mar. Chem., 83, 103-120, 2003.

Dortch, Q. and Conway, H. L.: Interactions between nitrate and ammonium uptake: variation with growth rate, nitrogen source and species, Mar. Biol., 79, 151-164, 1984.

Dortch, Q., Clayton Jr., J. R., Thoresen, S. S., and Ahmed, S. I.: Species differences in accumulation of nitrogen pools in phytoplankton, Mar. Biol., 81, 237-250, 1984.

Dubnick, A., Barker, J., Sharp, M., Wadham, J., Lis, G., Telling, J., Fitzsimons, S., and Jackson, M.: Characterization of dissolved organic matter (DOM) from glacial environments using total fluorescence spectroscopy and parallel factor analysis, Ann. Glaciol., 51, 111-122, 2010.

Fitznar, H. P., Lobbes, J. M., and Kattner, G.: Determination of enantiomeric amino acids with high-performance liquid chromatography and pre-column derivatisation with ophthaldialdehyde and $\mathrm{N}$-isobutyrylcysteine in seawater and fossil samples (mollusks), J. Chromatogr. A, 832, 123-132, 1999.

Hagen, J. O., Kohler, J., Melvold, K., and Winther, J.-G.: Glaciers in Svalbard: mass balance, runoff and freshwater flux, Polar Res., 22, 145-159, 2003.

Hasholt, B., Bobrovitskaya, N., Bogen, J., McNamara, J., Mernild, S. H., Milburn, D., and Walling, D. E.: Sediment transport to the 
Arctic Ocean and adjoining cold oceans, Nord. Hydrol., 37, 413432, 2006.

Hegseth, E. N. and Tverberg, V.: Effect of Atlantic water inflow on timing of the phytoplankton spring bloom in a high Arctic fjord (Kongsfjorden, Svalbard), J. Marine Syst., 113-114, 94105, 2013.

Hjelle, A.: Geology of Svalbard, Norwegian Polar Institute, Oslo, 1993.

Hodgkins, R.: Glacier hydrology in Svalbard, Norwegian high arctic, Quaternary Sci. Rev., 16, 957-973, 1997.

Hodson, A., Gurnell, A., Tranter, M., Bogen, J., Hagen, J. O., and Clark, M.: Suspended sediment yield and transfer processes in a small High-Arctic glacier basin, Svalbard, Hydrol. Process., 12, 73-86, 1998.

Hodson, A., Tranter, M., Gurnell, A., Clark, M., and Hagen, J. O.: The hydrochemistry of Bayelva, a high Arctic proglacial stream in Svalbard, J. Hydrol., 257, 91-114, 2002.

Holmes, R. M., McClelland, J. W., Peterson, B. J., Tank, S. E., Bulygina, E., Eglinton, T., Gordeev, V. V., Gurtovaya, T. Y., Raymond, P. A., Repeta, D. J., Staples, R., Striegl, R. G., Zhulidov, A. V., and Zimov, S. A.: Seasonal and Annual Fluxes of Nutrients and Organic Matter from Large Rivers to the Arctic Ocean and Surrounding Seas, Estuar. Coast., 35, 369-382, 2012.

Hood, E., Fellman, J., Spencer, R. G. M., Hernes, P. J., Edwards, R., D'Amore, D., and Scott, D.: Glaciers as a source of ancient and labile organic matter to the marine environment, Nature, 462, 1044-1047, 2009.

Hop, H., Pearson, T., Hegseth, E. N., Kovacs, K. M., Wiencke, C., Kwasniewski, S., Eiane, K., Mehlum, F., Gulliksen, B., Wlodarska-Kowalczuk, M., Lydersen, C., Weslawski, J. M., Cochrane, S., Gabrielsen, G. W., Leakey, R. J. G., Lønne, O. J., Zajaczkowski, M., Falk-Petersen, S., Kendall, M., Wängberg, S.-A., Bischof, K., Voronkov, A. Y., Kovaltchouk, N. A., Wiktor, J., Poltermann, M., di Prisco, G., Papucci, C., and Gerland, S.: The marine ecosystem of Kongsfjorden, Svalbard, Polar Res., 21, 167-208, 2002.

Hop, H., Falk-Petersen, S., Svendsen, H., Kwasniewski, S., Pavlov, V., Pavlova, O., and Søreide, J. E.: Physical and biological characteristics of the pelagic system across Fram Strait to Kongsfjorden, Prog. Oceanogr., 71, 182-231, 2006.

Huang, B., Hu, J., Xu, H., Cao, Z., and Wang, D.: Phytoplankton community at warm eddies in the northern South China Sea in winter 2003/2004, Deep-Sea Res. Pt. II, 57, 1792-1798, 2010.

Irvine-Fynn, T. D. L., Edwards, A., Newton, S., Langford, H., Rassner, S. M., Telling, J., Anesio, A. M., and Hodson, A. J.: Microbial cell budgets of an Arctic glacier surface quantified using flow cytometry, Environ. Microbiol., 14, 2998-3012, 2012.

Kaiser, K. and Benner, R.: Hydrolysis-induced racemization of amino acids, Limnol. Oceanogr.-Meth., 3, 318-325, 2005.

Kaiser, K. and Benner, R.: Major bacterial contribution to the ocean reservoir of detrital organic carbon and nitrogen, Limnol. Oceanogr., 53, 99-112, 2008.

Kuliñski, K., Kêdra, M., Legez`yńska, J., Gluchowska, M., and Zaborska, A.: Particulate organic matter sinks and sources in high Arctic fjord, J. Marine Syst., 139, 27-37, 2014.

Lang, C., Fettweis, X., and Erpicum, M.: Stable climate and surface mass balance in Svalbard over 1979-2013 despite the Arctic warming, The Cryosphere, 9, 83-101, doi:10.5194/tc-9-83-2015, 2015.
Latasa, M.: Improving estimations of phytoplankton class abundances using CHEMTAX, Mar. Ecol.-Prog. Ser., 329, 13-21, 2007.

Lawson, E. C., Wadham, J. L., Tranter, M., Stibal, M., Lis, G. P., Butler, C. E. H., Laybourn-Parry, J., Nienow, P., Chandler, D., and Dewsbury, P.: Greenland Ice Sheet exports labile organic carbon to the Arctic oceans, Biogeosciences, 11, 4015-4028, doi:10.5194/bg-11-4015-2014, 2014.

Mackey, M. D., Mackey, D. J., Higgins, H. W., and Wright, S. W.: CHEMTAX - a program for estimating class abundances from chemical markers: application to HPLC measurements of phytoplankton, Mar. Ecol.-Prog. Ser., 144, 265-283, 1996.

Mackey, M. D., Higgins, H. W., Mackey, D. J., and Wright, S. W.: CHEMTAX user's manual: a program for estimating class abundances from chemical markers-application to HPLC measurements of phytoplankton pigments, CSIRO Marine Laboratories, Hobart, Australia, 47 pp., 1997.

Mantoura, R. F. C. and Llewellyn, C. A.: The rapid determination of algal chlorophyll and carotenoid pigments and their breakdown products in natural waters by reverse-phase high-performance liquid chromatography, Anal. Chim. Acta, 152, 297-314, 1983.

Not, F., Massana, R., Latasa, M., Marie, D., Colson, C., Eikrem, W., Pedros-Alio, C., Vaulot, D., and Simon, N.: Late summer community composition and abundance of photosynthetic picoeukaryotes in Norwegian and Barents seas, Limnol. Oceanogr., 50, 1677-1686, 2005.

Opsahl, S., Benner, R., and Amon, R. M. W.: Major flux of terrigenous dissolved organic matter through the Arctic Ocean, Limnol. Oceanogr., 44, 2017-2023, 1999.

Piquet, A. M.-T., van de Poll, W. H., Visser, R. J. W., Wiencke, C., Bolhuis, H., and Buma, A. G. J.: Springtime phytoplankton dynamics in Arctic Krossfjorden and Kongsfjorden (Spitsbergen) as a function of glacier proximity, Biogeosciences, 11, 22632279, doi:10.5194/bg-11-2263-2014, 2014.

Redfield, A. C., Ketchum, B. H., and Richards, F. A.: The influence of organisms on the composition of seawater, in: The Sea, edited by: Hill, M. N., John Wiley, New York, 1963.

Rignot, E. and Kanagaratnam, P.: Changes in the Velocity Structure of the Greenland Ice Sheet, Science, 311, 986-990, 2006.

Rokkan Iversen, K. and Seuthe, L.: Seasonal microbial processes in a high-latitude fjord (Kongsfjorden, Svalbard): I. Heterotrophic bacteria, picoplankton and nanoflagellates, Polar Biol., 34, 731749, 2011.

Schulz, K. G., Bellerby, R. G. J., Brussaard, C. P. D., Büdenbender, J., Czerny, J., Engel, A., Fischer, M., Koch-Klavsen, S., Krug, S. A., Lischka, S., Ludwig, A., Meyerhöfer, M., Nondal, G., Silyakova, A., Stuhr, A., and Riebesell, U.: Temporal biomass dynamics of an Arctic plankton bloom in response to increasing levels of atmospheric carbon dioxide, Biogeosciences, 10, 161180, doi:10.5194/bg-10-161-2013, 2013.

Sharp, M., Parkes, J., Cragg, B., Fairchild, I. J., Lamb, H., and Tranter, M.: Widespread bacterial populations at glacier beds and their relationship to rock weathering and carbon cycling, Geology, 27, 107-110, 1999.

Smith, R. W., Bianchi, T. S., Allison, M., Savage, C., and Galy, V.: High rates of organic carbon burial in fjord sediments globally, Nat. Geosci., 8, 450-453, 2015.

Stibal, M., Tranter, M., Benning, L. G., and Øehák, J.: Microbial primary production on an Arctic glacier is insignificant in com- 
parison with allochthonous organic carbon input, Environ. Microbiol., 10, 2172-2178, 2008.

Svendsen, H., Beszczynska-Møller, A., Hagen, J. O., Lefauconnier, B., Tverberg, V., Gerland, S., Ørbøk, J. B., Bischof, K., Papucci, C., Zajaczkowski, M., Azzolini, R., Bruland, O., Wiencke, C., Winther, J.-G., and Dallmann, W.: The physical environment of Kongsfjorden-Krossfjorden, an Arctic fjord system in Svalbard, Polar Res., 21, 133-166, 2002.

Tye, A. M. and Heaton, T. H. E.: Chemical and isotopic characteristics of weathering and nitrogen release in non-glacial drainage waters on Arctic tundra, Geochim. Cosmochim. Ac., 71, 41884205, 2007.

Vandewiele, S., Cowie, G., Soetaert, K., and Middelburg, J. J.: Amino acid biogeochemistry and organic matter degradation state across the Pakistan margin oxygen minimum zone, DeepSea Res. Pt. II, 56, 318-334, 2009.

van Heukelem, L. and Thomas, C. S.: Computer-assisted highperformance liquid chromatography method development with applications to the isolation and analysis of phytoplankton pigments, J. Chromatogr. A, 910, 31-49, 2001.
Wadham, J. L., Hodson, A. J., Tranter, M., and Dowdeswell, J. A.: The hydrochemistry of meltwaters draining a polythermal-based, high Arctic glacier, south Svalbard: I. The ablation season, Hydrol. Process., 12, 1825-1849, 1998.

Wehmiller, J. F., Harris, W. B., Boutin, B. S., and Farrell, K. M.: Calibration of amino acid racemization (AAR) kinetics in United States mid-Atlantic Coastal Plain Quaternary mollusks using 87Sr/86Sr analyses: Evaluation of kinetic models and estimation of regional Late Pleistocene temperature history, Quat. Geochronol., 7, 21-36, 2012.

Wu, Y., Eglinton, T., Yang, L., Deng, B., Montluçon, D., and Zhang, J.: Spatial variability in the abundance, composition, and age of organic matter in surficial sediments of the East China Sea, J. Geophys. Res.-Biogeo., 118, 1495-1507, doi:10.1002/2013JG002286, 2013.

Zhu, Z. Y., Wu, Y., Zhang, J., Dittmar, T., Li, Y., Shao, L., and Ji, Q.: Can primary production contribute non-labile organic matter in the sea: Amino acid enantiomers along the coast south of the Changjiang Estuary in May, J. Marine Syst., 129, 343-349, 2014. 